\title{
Sox 2 is an oncogenic driver of small cell lung cancer
}

\author{
Ellen Voigt ${ }^{1,2}$, Hannah Wollenzien ${ }^{1,2,3}$, Josh Feiner ${ }^{4}$, Ethan Thompson ${ }^{1,2}$, Madeline Vande \\ Kamp $^{1,2}$, Michael S. Kareta ${ }^{1,2,3,5,6, *}$
}

\begin{abstract}
${ }^{1}$ Genetics \& Genomics Group and the ${ }^{2}$ Cancer Biology and Immunotherapies Group, Sanford Research, Sioux Falls, South Dakota, USA. ${ }^{3}$ Division of Basic Biomedical Sciences, University of South Dakota, Vermillion, South Dakota, USA. ${ }^{4}$ Dakota Wesleyan University, Mitchel, South Dakota, USA. ${ }^{5}$ Department of Pediatrics, Sanford School of Medicine, Sioux Falls, South Dakota, USA. ${ }^{6}$ Department of Biochemistry, South Dakota State University, Brookings, South Dakota, USA.

Correspondence may be addressed to M.K. (michael.kareta@ sanfordhealth.org)
\end{abstract}

\begin{abstract}
Although many cancer prognoses have improved in the past fifty years due to advancements in treatments, there has been little to no improvement in therapies for small cell lung cancer (SCLC) which currently has a five-year survival rate of less than $7 \%$. One promising avenue to improve treatment for SCLC is to understand its underlying genetic alterations that drive its formation and growth. One such mutation in SCLC, which appears in many cancers, is of the $R b$ gene. When mutated, $R b$ causes hyperproliferation and loss of cellular identity. Normally $R b$ promotes differentiation by regulating lineage specific transcription factors including regulation of pluripotency factors such as Sox2. However, there is evidence that when certain tissues lose $R b$, Sox 2 becomes upregulated and promotes oncogenesis. To better understand the relationship between $R b$ and Sox 2 and to uncover new treatments for SCLC we have studied the role of Sox2 in $R b$ loss initiated tumors by investigating both the tumor initiation in SCLC genetically engineered mouse models, as well as tumor maintenance in SCLC cell lines.
\end{abstract}




\section{Introduction}

Small cell lung cancer (SCLC) is a devastating disease where survival rates are typically measured in 2-year segments, rather than the typical 5. Its low rate of detection at early stages is exacerbated by its ability for rapid metastasis and almost invariable resistance to therapy (1). Patients who are stricken by this disease face a $6 \%$ 2-year survival rate while most will succumb less than a year after diagnosis (2). Despite this alarming statistic, the standard of care for treating SCLC has remained essentially the same for the past 40 years and few innovations have been developed. Patients still rely on platinum-based drugs that are not ideal because of their lack of precision. Just as researchers have found new drugs for many other cancers based on their DNA mutations, scientists have looked for new drugs to treat SCLC. In the pursuit of these new therapies, researchers begin by seeking to understand the underlying genetic causes of SCLC.

As in many other cancers, the retinoblastoma protein $(R b)$ is lost in SCLC (6-12). Normally $R b$ is recognized for its responsibility in the regulation of the cell cycle but it also interacts with many lineage-specific transcription factors (1). One of the transcription factors regulated by $R b$ is Sox2 (2). Known primarily as a pluripotency factor, Sox2 is also a key master regulator of neural and neuroendocrine cell types (3-7). As a master regulator, Sox2 influences cell identity early and widely in the cell fate decisions. Pulmonary neuroendocrine cells are a common cell of origin for SCLC, therefore is possible that Sox 2 activity in neuroendocrine cells following $R b$ loss induces stem or progenitor genetic networks that help to drive oncogenesis. To that end, we generated a conditional knockout mouse in which we could perturb Sox2 activity in a SCLC mouse model to assess the consequence of SCLC formation after Sox2 loss. We observed that Sox2 is indeed required for SCLC formation, validating Sox2 as an oncogenic driver of SCLC. 


\section{Experimental Methods}

\section{Ethics statement}

Mice were maintained according to the guidelines set for the by the NIH and were housed in the Sanford Research Animal Research Center, accredited by AAALAC using protocols reviewed by our local IUACUC.

\section{SCLC mouse tumor initiation}

We modeled SCLC in the $R b^{\text {lox/lox }}, p 53^{\text {lox/lox }}, p 130^{\text {lox/lox }}, \operatorname{Ros} a^{\text {luc }}$ mouse line (8). Sox $2^{+/++/ l o x}$, and $^{\text {lox/lox }}$. To study SCLC tumor initiation, we injected Cre-recombinase adenovirus (Baylor Vector Core) into the mouse lungs by intratracheal injection to excise the floxed genes. The mice were assigned to either a six-month cohort, a three-month cohort or the survival curve. Mouse lungs, livers, and any tumors were harvested for immunohistochemistry.

\section{SCLC cell lines}

We used the murine SCLC cell lines KP1 and KP3 and the human SCLC lines NJH29 (H29) and NCI-H82 (H82) $(8,9)$. The cells were maintained in suspension and cultured in RPMI with $10 \%$ bovine growth serum and penicillin/streptomycin.

\section{SCLC lung and liver immunohistochemistry}

The Sanford Research Pathology Core performed the immunohistochemistry for this study. The mouse lungs, livers and tumors were stained with H\&E, for Sox2, calcitonin (Sigma, 38198 1:2,000), anti-phospho-histone H3 (EMD Millipore 06-570 1:500), cleaved caspase 3 (CST-9664 1:100), ki67.

Tissue image analysis and statistics 
We used Cell Profiler to count the tumors unbiasedly and to determine whether they are CGRP+ to identify them as SCLC over another kind of cancer.

\section{Lentiviral and siRNA transfection}

We made the lentivirus using the packaging plasmids VSVG, pMDL, and RSV in 293T cells. Virus was concentrated and titired for reproducible transductions. We measure their viability after the knock down with an alamar blue assay, and the levels of apoptosis with Annexin V and flow cytometry. qPCR was used to confirm the knock down of Sox 2 in the cells.

\section{Results}

To investigate if Sox 2 is required for the formation of SCLS, we bred a mouse line containing a conditional Sox2 allele (Sox $\left.2^{\text {lox/lox }}\right)$ to an existing mouse models for SCLC. This mouse, consisting of $R b^{\text {lox/lox}} ; p 130^{\text {lox/lox}} ; p 53^{\text {lox/lox }} ;$ Rosa $26^{\text {LSL-Luciferase }}$ alleles, displays all the hallmarks of human SCLC, mainly the same histological characteristics, rapid metastasis, and chemoresistance $(8,10,11)$. To overcome the dramatic effects of $R b$ - and $p 53$-loss in the mouse, we localized Cre-mediated recombination to the lung by the intratracheal instillation of a Creexpressing adenovirus (Adeno-Cre). Due to the presence of the floxed pl30 allele (8), we observed early tumors around 3-months, with a robust tumor burden 6-months after Crerecombination (Figure 1).

We bred this SCLC mouse line with a Sox $2^{\text {lox/lox }}$ line, ensuring that we generated mice of all three potential Sox2 genotypes: Sox $2^{+/+}, \operatorname{Sox} 2^{+/ l o x}$, and Sox $2^{\text {lox/lox }}$. By this strategy, we can determine if one or both alleles of Sox 2 may be involved in SCLC formation. Tumors were initiated by Adeno-Cre, and as expected $R b \Delta ; p 53 \Delta ; p 130 \Delta$ mice showed a sizeable number of tumor foci showing the histological characteristics of SCLC 6 months after Cre infection (Figure 
2) $(8,12)$. The $R b \Delta ; p 53 \Delta ; p 130 \Delta ;$ Sox $2 \Delta$ mice had a nearly complete loss of SCLC foci observed at the same timepoint (Figure 2A,B). We observe a significant lengthening of the lifespan of the $R b \Delta ; p 53 \Delta ; p 130 \Delta ;$ Sox $2 \Delta$ mice (Figure 2C). Finally, to fully characterize these tumors and ensure Sox 2 loss in the $R b \Delta ; p 53 \Delta ; p 130 \Delta ;$ Sox $2 \Delta$ mice, we have optimized immunohistochemistry staining and an unbiased image analysis pipeline to identify and characterize these tumors to perform thorough statistical analysis of the $R b \Delta ; p 53 \Delta ; p 130 \Delta$; Sox $2^{+}$tumors compared to the few $R b \Delta ; p 53 \Delta ; p 130 \Delta ;$ Sox $2 \Delta$ tumors (Figures 2D and 2E). Indeed, of the few tumors $R b \Delta ; p 53 \Delta ; p 130 \Delta ; \operatorname{Sox} 2 \Delta$ tumors, a plurality showed immunoreactivity to Sox 2 antibodies, indicating that they are the result of incomplete Cre function. However, a small number of $R b \Delta ; p 53 \Delta ; p 130 \Delta$; Sox $2 \Delta$ tumors appeared to be Sox $2 \Delta$ indicating that Sox2 activity may not be necessary in some SCLC tumors.

To investigate the requirement for the $R b-\operatorname{Sox} 2$ axis in the growth and maintenance of already established tumors, murine cell lines for SCLC were infected with adenovirus harboring $R b$ and a GFP reporter (Adeno-Rb-GFP) or GFP alone (Adeno-GFP). After sorting for $\mathrm{GFP}^{+}$cells, the SCLC cell lines showed reduction of Sox2 upon overexpression of $R b$ (Figure 3A). As $R b$ overexpression in mouse SCLC will slow the growth of established tumors (13), we sought to determine if knockdown of Sox2 would have deleterious effects on the cancer cells. Indeed, we observed that short hairpin-mediated knockdown of Sox2 (shSox2) achieve a 60-90\% knockdown by RT-qPCR (Figure 3B) and resulted in an increase in cell death (Figure 3C). Sox2 knockdown also dramatically reduced the growth of both mouse and human SCLC cell lines (Figure 3D). 


\section{Discussion}

Sox2 is an essential transcription factor, and has been observed to be misregulated in various cancer of the epithelium. As a cancer that rises from the lung epithelium, it seemed reasonable that Sox2 may indeed be a driver of SCLC (12). Furthermore, we had previously observed that $\mathrm{Rb}$ specifically binds to and repressed the core pluripotency network, including Sox2 (2). As SCLC is initiated in part, by loss of $R b$ it was possible that $R b$-loss resulted in Sox 2 upregulation, which might drive $\operatorname{SCLC}(10,14,15)$. Indeed, SCLC oftentimes shows amplification of Sox2 (14). Therefore, this data and others shows that Sox2 activity is indeed a driver of SCLC (14). We did, however, observe a small minority of $R b \Delta ; p 53 \Delta ; p 130 \Delta ;$ Sox $2 \Delta$ tumors. Whether these tumors were indeed independent of Sox 2 activity, or if they received signaling from the microenvironment which activated Sox2 target genes in the absence of Sox2 is currently unclear.

One potential interesting facet of SCLC biology is the realization that it is not a homogenous disease; rather it is characterized by four different subtypes (16). The $R b^{\text {lox/lox}} ; p 130^{\text {lox/lox}}$; $p 53^{\text {lox/lox }}$ mouse model predominantly gives rise to the most prevalent subtype of SCLC, SCLCA (17). SCLC-A is characterized by strong expression of the neural bHLH transcription factor, Ascll $(18,19)$. In neural cells, Ascll is a direct target of Sox2 (20-22). Therefore, in SCLC, a neuroendocrine tumor, Sox2 activity may upregulate Ascll. Sox2 may therefore may bridge the loss of $R b$ and Ascll. However, the exact mechanism that Sox2 may have in the regulation of Ascll, or in the major genetic determinants of the other SCLC subtypes is currently unclear. What these results do indicate is that Sox 2 is required for SCLC, and may in the future may be a potential biomarker or therapeutic target towards the treatment of this devastating disease. 


\section{Acknowledgements}

We would like to acknowledge the NIGMS Center for Pediatric Research for funding support (5P20GM103620-04). Also the Sanford Research Pathology and Flow Cytomotry Cores, which are supported by the NIGMS (P20GM103548).

\section{References}

1. Burkhart DL, Sage J. Cellular mechanisms of tumour suppression by the retinoblastoma gene. Nat Rev Cancer. 2008;8(9):671-82. Epub 2008/07/25. doi: nrc2399 [pii] 10.1038/nrc2399. PubMed PMID: 18650841.

2. Kareta MS, Gorges LL, Hafeez S, Benayoun BA, Marro S, Zmoos AF, Cecchini MJ, Spacek D, Batista LF, O'Brien M, Ng YH, Ang CE, Vaka D, Artandi SE, Dick FA, Brunet A, Sage J, Wernig M. Inhibition of pluripotency networks by the rb tumor suppressor restricts reprogramming and tumorigenesis. Cell Stem Cell. 2015;16(1):39-50. doi: 10.1016/j.stem.2014.10.019. PubMed PMID: 25467916.

3. Abdelalim EM, Emara MM, Kolatkar PR. The SOX transcription factors as key players in pluripotent stem cells. Stem Cells Dev. 2014;23(22):2687-99. Epub 2014/08/16. doi: 10.1089/scd.2014.0297. PubMed PMID: 25127330.

4. Arnold K, Sarkar A, Yram MA, Polo JM, Bronson R, Sengupta S, Seandel M, Geijsen N, Hochedlinger K. Sox2(+) adult stem and progenitor cells are important for tissue regeneration and survival of mice. Cell Stem Cell. 2011;9(4):317-29. doi: 10.1016/j.stem.2011.09.001. PubMed PMID: 21982232; PMCID: PMC3538360.

5. Avilion AA, Nicolis SK, Pevny LH, Perez L, Vivian N, Lovell-Badge R. Multipotent cell lineages in early mouse development depend on SOX2 function. Genes Dev. 2003;17(1):126-40. doi: 10.1101/gad.224503. PubMed PMID: 12514105; PMCID: 195970.

6. Driessens G, Blanpain C. Long live sox2: sox2 lasts a lifetime. Cell Stem Cell. 2011;9(4):283-4. Epub 2011/10/11. doi: 10.1016/j.stem.2011.09.007. PubMed PMID: 21982223.

7. Ellis P, Fagan BM, Magness ST, Hutton S, Taranova O, Hayashi S, McMahon A, Rao M, Pevny L. SOX2, a persistent marker for multipotential neural stem cells derived from embryonic stem cells, the embryo or the adult. Dev Neurosci. 2004;26(2-4):148-65. doi: 10.1159/000082134. PubMed PMID: 15711057.

8. Schaffer BE, Park KS, Yiu G, Conklin JF, Lin C, Burkhart DL, Karnezis AN, SweetCordero EA, Sage J. Loss of p130 accelerates tumor development in a mouse model for human small-cell lung carcinoma. Cancer Res. 2010;70(10):3877-83. doi: 10.1158/00085472.CAN-09-4228. PubMed PMID: 20406986; PMCID: PMC2873158.

9. Jahchan NS, Dudley JT, Mazur PK, Flores N, Yang D, Palmerton A, Zmoos AF, Vaka D, Tran KQ, Zhou M, Krasinska K, Riess JW, Neal JW, Khatri P, Park KS, Butte AJ, Sage J. A drug repositioning approach identifies tricyclic antidepressants as inhibitors of small cell 
lung cancer and other neuroendocrine tumors. Cancer Discov. 2013;3(12):1364-77. doi: 10.1158/2159-8290.CD-13-0183. PubMed PMID: 24078773; PMCID: PMC3864571.

10. Meuwissen R, Linn SC, Linnoila RI, Zevenhoven J, Mooi WJ, Berns A. Induction of small cell lung cancer by somatic inactivation of both Trp53 and Rb1 in a conditional mouse model. Cancer Cell. 2003;4(3):181-9. Epub 2003/10/03. doi: S1535610803002204 [pii]. PubMed PMID: 14522252.

11. Park KS, Liang MC, Raiser DM, Zamponi R, Roach RR, Curtis SJ, Walton Z, Schaffer BE, Roake CM, Zmoos AF, Kriegel C, Wong KK, Sage J, Kim CF. Characterization of the cell of origin for small cell lung cancer. Cell Cycle. 2011;10(16):2806-15. Epub 2011/08/09. doi: 17012 [pii]. PubMed PMID: 21822053.

12. Sutherland KD, Proost N, Brouns I, Adriaensen D, Song JY, Berns A. Cell of origin of small cell lung cancer: inactivation of Trp53 and Rb1 in distinct cell types of adult mouse lung. Cancer Cell. 2011;19(6):754-64. doi: 10.1016/j.ccr.2011.04.019. PubMed PMID: 21665149.

13. Nikitin AY, Juarez-Perez MI, Li S, Huang L, Lee WH. RB-mediated suppression of spontaneous multiple neuroendocrine neoplasia and lung metastases in $\mathrm{Rb}+/-$ mice. Proc Natl Acad Sci U S A. 1999;96(7):3916-21. PubMed PMID: 10097138; PMCID: PMC22395.

14. Rudin CM, Durinck S, Stawiski EW, Poirier JT, Modrusan Z, Shames DS, Bergbower EA, Guan Y, Shin J, Guillory J, Rivers CS, Foo CK, Bhatt D, Stinson J, Gnad F, Haverty PM, Gentleman R, Chaudhuri S, Janakiraman V, Jaiswal BS, Parikh C, Yuan W, Zhang Z, Koeppen H, Wu TD, Stern HM, Yauch RL, Huffman KE, Paskulin DD, Illei PB, VarellaGarcia M, Gazdar AF, de Sauvage FJ, Bourgon R, Minna JD, Brock MV, Seshagiri S. Comprehensive genomic analysis identifies SOX2 as a frequently amplified gene in smallcell lung cancer. Nat Genet. 2012;44(10):1111-6. Epub 2012/09/04. doi: ng. 2405 [pii] 10.1038/ng.2405. PubMed PMID: 22941189.

15. George J, Lim JS, Jang SJ, Cun Y, Ozretic L, Kong G, Leenders F, Lu X, FernandezCuesta L, Bosco G, Muller C, Dahmen I, Jahchan NS, Park KS, Yang D, Karnezis AN, Vaka D, Torres A, Wang MS, Korbel JO, Menon R, Chun SM, Kim D, Wilkerson M, Hayes N, Engelmann D, Putzer B, Bos M, Michels S, Vlasic I, Seidel D, Pinther B, Schaub P, Becker C, Altmuller J, Yokota J, Kohno T, Iwakawa R, Tsuta K, Noguchi M, Muley T, Hoffmann H, Schnabel PA, Petersen I, Chen Y, Soltermann A, Tischler V, Choi CM, Kim YH, Massion PP, Zou Y, Jovanovic D, Kontic M, Wright GM, Russell PA, Solomon B, Koch I, Lindner M, Muscarella LA, la Torre A, Field JK, Jakopovic M, Knezevic J, Castanos-Velez E, Roz L, Pastorino U, Brustugun OT, Lund-Iversen M, Thunnissen E, Kohler J, Schuler M, Botling J, Sandelin M, Sanchez-Cespedes M, Salvesen HB, Achter V, Lang U, Bogus M, Schneider PM, Zander T, Ansen S, Hallek M, Wolf J, Vingron M, Yatabe Y, Travis WD, Nurnberg P, Reinhardt C, Perner S, Heukamp L, Buttner R, Haas SA, Brambilla E, Peifer M, Sage J, Thomas RK. Comprehensive genomic profiles of small cell lung cancer. Nature. 2015;524(7563):47-53. doi: 10.1038/nature14664. PubMed PMID: 26168399.

16. Rudin CM, Poirier JT, Byers LA, Dive C, Dowlati A, George J, Heymach JV, Johnson JE, Lehman JM, MacPherson D, Massion PP, Minna JD, Oliver TG, Quaranta V, Sage J, Thomas RK, Vakoc CR, Gazdar AF. Molecular subtypes of small cell lung cancer: a 
synthesis of human and mouse model data. Nat Rev Cancer. 2019;19(5):289-97. doi: 10.1038/s41568-019-0133-9. PubMed PMID: 30926931.

17. Mollaoglu G, Guthrie MR, Bohm S, Bragelmann J, Can I, Ballieu PM, Marx A, George J, Heinen C, Chalishazar MD, Cheng H, Ireland AS, Denning KE, Mukhopadhyay A, Vahrenkamp JM, Berrett KC, Mosbruger TL, Wang J, Kohan JL, Salama ME, Witt BL, Peifer M, Thomas RK, Gertz J, Johnson JE, Gazdar AF, Wechsler-Reya RJ, Sos ML, Oliver TG. MYC Drives Progression of Small Cell Lung Cancer to a Variant Neuroendocrine Subtype with Vulnerability to Aurora Kinase Inhibition. Cancer Cell. 2017;31(2):270-85. doi: 10.1016/j.ccell.2016.12.005. PubMed PMID: 28089889; PMCID: PMC5310991.

18. Augustyn A, Borromeo M, Wang T, Fujimoto J, Shao C, Dospoy PD, Lee V, Tan C, Sullivan JP, Larsen JE, Girard L, Behrens C, Wistuba, II, Xie Y, Cobb MH, Gazdar AF, Johnson JE, Minna JD. ASCL1 is a lineage oncogene providing therapeutic targets for high-grade neuroendocrine lung cancers. Proc Natl Acad Sci U S A. 2014;111(41):1478893. doi: 10.1073/pnas.1410419111. PubMed PMID: 25267614; PMCID: 4205603.

19. Borromeo MD, Savage TK, Kollipara RK, He M, Augustyn A, Osborne JK, Girard L, Minna JD, Gazdar AF, Cobb MH, Johnson JE. ASCL1 and NEUROD1 Reveal Heterogeneity in Pulmonary Neuroendocrine Tumors and Regulate Distinct Genetic Programs. Cell reports. 2016;16(5):1259-72. doi: 10.1016/j.celrep.2016.06.081. PubMed PMID: 27452466; PMCID: PMC4972690.

20. Cimadamore F, Fishwick K, Giusto E, Gnedeva K, Cattarossi G, Miller A, Pluchino S, Brill LM, Bronner-Fraser M, Terskikh AV. Human ESC-derived neural crest model reveals a key role for SOX2 in sensory neurogenesis. Cell Stem Cell. 2011;8(5):538-51. doi: 10.1016/j.stem.2011.03.011. PubMed PMID: 21549328; PMCID: PMC4110917.

21. Amador-Arjona A, Cimadamore F, Huang CT, Wright R, Lewis S, Gage FH, Terskikh AV. SOX2 primes the epigenetic landscape in neural precursors enabling proper gene activation during hippocampal neurogenesis. Proc Natl Acad Sci U S A. 2015;112(15):E1936-45. doi: 10.1073/pnas.1421480112. PubMed PMID: 25825708; PMCID: PMC4403144.

22. Lodato MA, Ng CW, Wamstad JA, Cheng AW, Thai KK, Fraenkel E, Jaenisch R, Boyer LA. SOX2 co-occupies distal enhancer elements with distinct POU factors in ESCs and NPCs to specify cell state. PLoS Genet. 2013;9(2):e1003288. doi: 10.1371/journal.pgen.1003288. PubMed PMID: 23437007; PMCID: PMC3578749. 


\section{Figure Legends}

Figure 1 Genetically engineered mouse model for the study of Sox2 in SCLC.

Figure 2 SCLC tumors show a requirement for Sox 2. A) SCLC was initiated by intratracheal injection of Adeno-Cre virus and the H\&E stained lungs were screened for SCLC foci at 6 months. Scale bar $=4 \mathrm{~mm}$.

B) Quantification of tumor foci observed in SCLC mice at 6 months. C) Survival curve of Sox2+ and Sox $2 \Delta$ mice. D) Immunohistochemistry of tumors for growth markers Ki67, Phospho-histone H3 (PhosphoH3), and cleaved caspase 3 (CC3), and the neuroendocrine markers Chga and Sox2. E) Automated tumor identification by Chga staining, shown as colored areas (right).

Figure $3 \mathrm{Rb}$ regulates Sox 2 in SCLC and affects cellular viability and growth. A) Expression of Rb and Sox2 in GFP+ sorted SCLC cell lines infected with Adeno-Rb-GFP relative to Adeno-GFP. B) Knockdown efficiency of 3 murine Sox 2 shRNAs (shSox2-1,2,4) and one human hairpin (shSOX2-5), plotted relative to a non-targeting hairpin control. C) Annexin V labeling of apoptotic cells after transduction with shSox2 or control hairpins in two human SCLC cell lines. High numbers of apoptotic cells are due to residual dead cells after Puromycin treatment to select transduced cells (shSox 2 or controls). Due to the non-adherent nature of these cell lines, dead cells are difficult to fully remove before further testing. D) Alamar blue assay to measure growth of mouse and human SCLC cell lines after transduction with Sox 2 hairpins or controls. Error is the biological variance between two different murine (KP1 \& KP3) or human cell lines (H29 \& H82). 


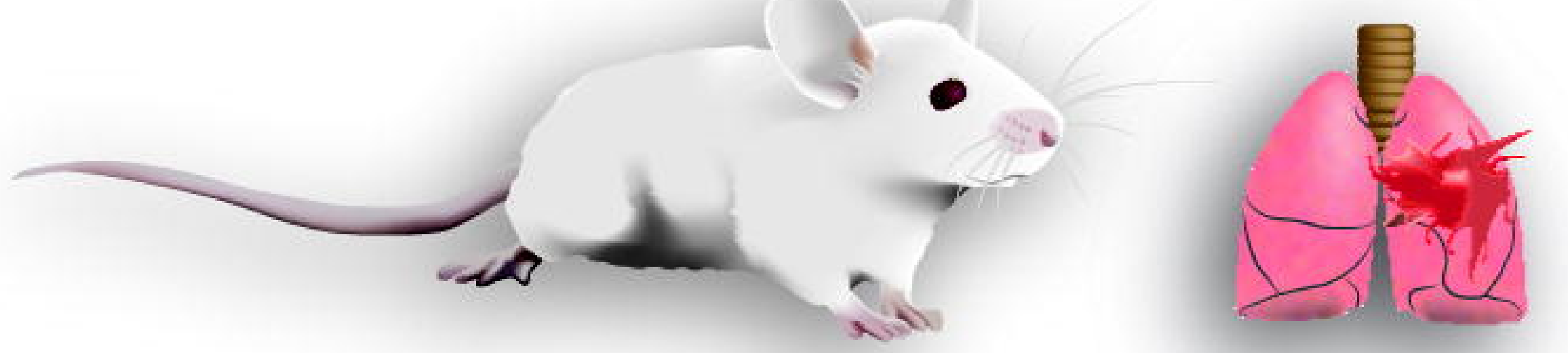

\section{Small cell lung cancer}

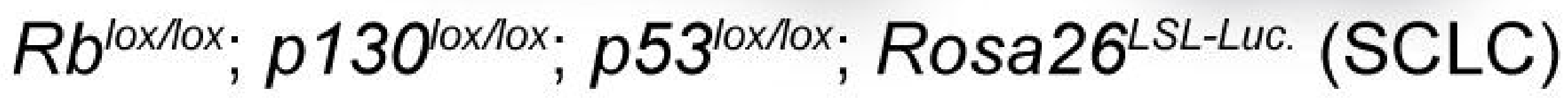

$R b^{10 x / 10 x} ; p 130^{10 x / 10 x} ; p 53^{10 x / 10 x} ;$ Sox2 $2^{10 x / 10 x} ;$ Rosa26 LSL-Luc. (SCLC-Sox2) 
A

\section{B}

C

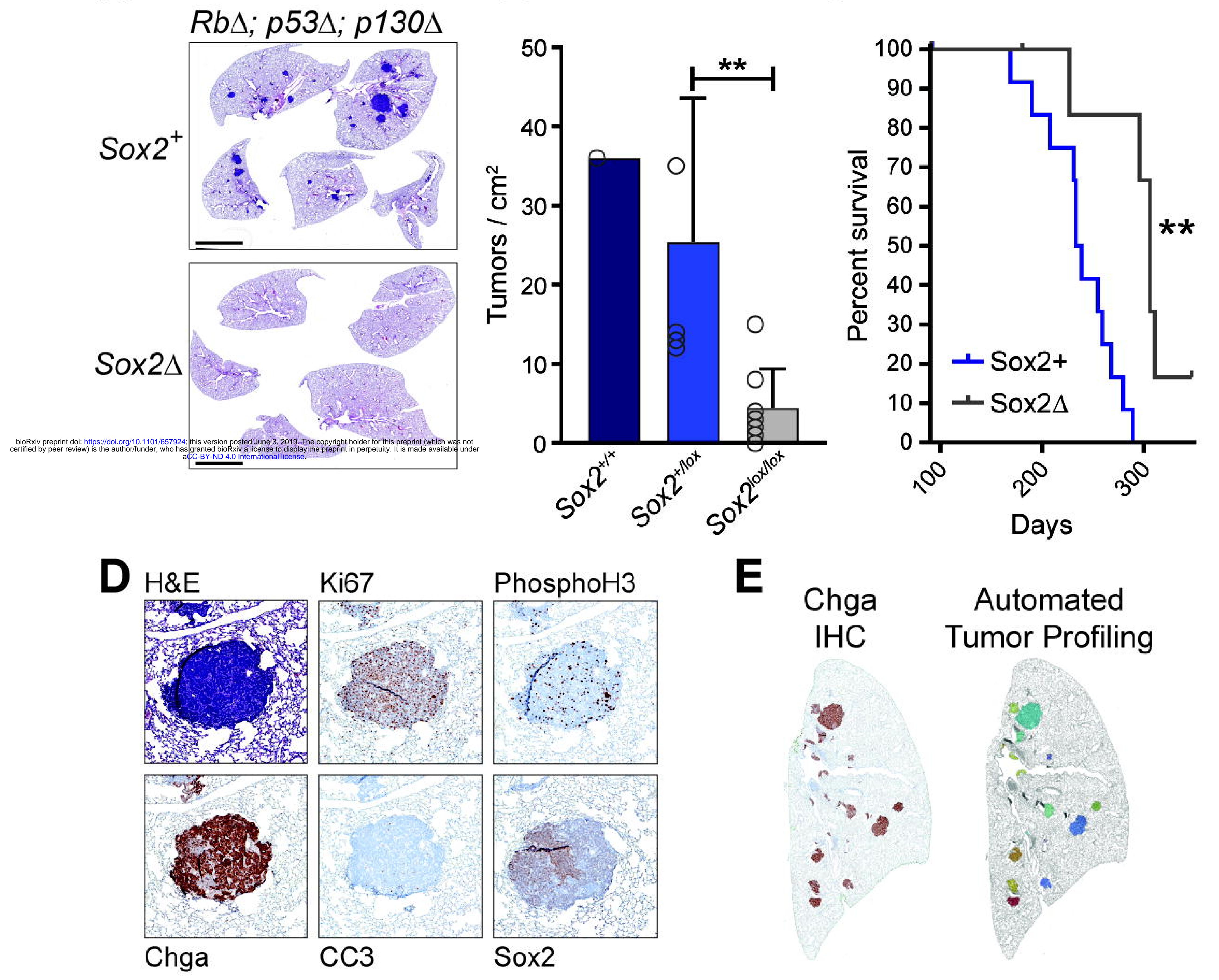


